\title{
RESEARCH IN SPORT \\ PHYSICAI ACC \\ Acute and chronic IL-6 responses during full season training in young swimmers
}

$\begin{array}{ll}\text { Autor(es): } \quad & \text { Nafpaktitou, D.; Philippou, A.; Vagiakakos, G.; Vagiakakos, N.; } \\ & \text { Mantaloufas, M.; Chrousos, G.; Koutsilieris, M.; Platanou, T. }\end{array}$

Publicado por: Imprensa da Universidade de Coimbra

URL persistente:

URI:http://hdl.handle.net/10316.2/44121

DOI:

DOI:https://doi.org/10.14195/2182-7087_ex2018_58

Accessed : $\quad$ 26-Apr-2023 12:50:33

A navegação consulta e descarregamento dos títulos inseridos nas Bibliotecas Digitais UC Digitalis, UC Pombalina e UC Impactum, pressupõem a aceitação plena e sem reservas dos Termos e Condições de Uso destas Bibliotecas Digitais, disponíveis em https://digitalis.uc.pt/pt-pt/termos.

Conforme exposto nos referidos Termos e Condições de Uso, o descarregamento de títulos de acesso restrito requer uma licença válida de autorização devendo o utilizador aceder ao(s) documento(s) a partir de um endereço de IP da instituição detentora da supramencionada licença.

Ao utilizador é apenas permitido o descarregamento para uso pessoal, pelo que o emprego do(s) título(s) descarregado(s) para outro fim, designadamente comercial, carece de autorização do respetivo autor ou editor da obra.

Na medida em que todas as obras da UC Digitalis se encontram protegidas pelo Código do Direito de Autor e Direitos Conexos e demais legislação aplicável, toda a cópia, parcial ou total, deste documento, nos casos em que é legalmente admitida, deverá conter ou fazer-se acompanhar por este aviso. 


\section{ANNALS OF RESEARCH IN SPORT AND PHYSICAL ACTIVITY}




\title{
ACUTE AND CHRONIC IL-6 RESPONSES DURING FULL SEASON TRAINING IN YOUNG SWIMMERS
}

\author{
D. Nafpaktitou1, A. Philippou², G. Vagiakakos, N. Vagiakakos, M. Mantaloufas, G. \\ Chrousos $^{3}$, M. Koutsilieris², and T. Platanou ${ }^{1}$
}

KEYWORDS: IL-6, acute effect, chronic effect, swimming training

It is well established that strenuous prolonged exercise suppresses various aspects of immune function, while excessive exercise not accompanied by sufficient rest periods may induce a chronic, low-level systemic inflammation. This exercise-induced negative effect can be counteracted by the production of anti-inflammatory cytokines, among which interleukin (IL)- 6 has a dominant role. Swimming training is very hard and may lead to chronic fatigue syndrome associated with immunosuppression. This study was undertaken to investigate the acute and chronic effects of a full season swimming training on serum IL-6 both at rest and after maximal exercise testing in young swimmers. Twelve well-trained male swimmers (14.08 $\pm 1.0 \mathrm{yrs})$ participated in the study. Measurements were carried out at the beginning of the training season (T1) and pre and post the taper of each of the two competitive periods (i.e., T2, T3 for the first macrocycle, and T4, T5 for the second macrocycle, respectively). At each of the above time points, blood samples were collected pre and 1 hour post a maximal, 400m swimming testing. Serum IL-6 levels were measured by ELISA using a commercially available kit and adjustment for plasma volume changes were performed before data analysis. Significant pre-post testing differences were found at T1 $(p=0.005)$ and T2 $(p=0.005)$. There were no significant differences among the post testing values throughout the experimental period, although there was a tendency for IL- 6 to increase over time. Rest IL- 6 values were significantly different only between T2 and T5 ( $p$ $=0.040$ ), although there was also a tendency for the rest values to increase from T2 to T5, while at $\mathrm{T} 1$ and $\mathrm{T} 2$ they were similar. These findings indicate that acute (pre-post testing)

\footnotetext{
1 School of Physical Education and Sport Science.

2 Department of Physiology.

3 First Department of Pediatrics, National and Kapodistrian University of Athens, Greece

Email: nafpaktid@phed.uoa.gr; nafpaktitoud@cosmotemail.gr
} 
IL-6 responses are greater during the first swimming training macrocycle, while prolonged training may activate an adaptive mechanism, which attenuates the magnitude of these responses. Interestingly, long-term training induces an increase in rest serum IL-6. Our findings appear to confirm the notion that IL-6 is a double-edged sword, exhibiting a biphasic, training-induced pattern with large, acute systemic elevations post-exercise and chronic, low-grade increases during long-term exercise training.

Special thanks go to the swimmers and Drs L.Margeti and S. Kotroni. 